Article

\title{
Reconstituting the Urban Commons: Public Space, Social Capital and the Project of Urbanism
}

\author{
David Brain ${ }^{1,2}$ \\ ${ }^{1}$ Division of Social Sciences, New College of Florida, Sarasota, FL 34243, USA; E-Mail: brain@ncf.edu \\ ${ }^{2}$ Centre for the Future of Places, KTH-Royal Institute of Technology, 10044 Stockholm, Sweden
}

Submitted: 17 February 2019 | Accepted: 15 April 2019 | Published: 30 June 2019

\begin{abstract}
This article outlines a framework for connecting design-oriented research on accommodating and encouraging social interaction in public space with investigation of broader questions regarding civic engagement, social justice and democratic governance. How can we define the "kind of problem a city is" (Jacobs, 1961), simultaneously attending to the social processes at stake in urban places, the spatial ordering of urban form and the construction of the forms of agency that enable us to make better places on purpose? How can empirical research be connected more systematically to theories of democratic governance, with clear implications for urban design, urban and regional planning as professional practice? This framework connects three distinct theoretical moves: (1) understanding the sociological implications of public space as an urban commons, (2) connecting the making of public space to research on social capital and collective efficacy, and (3) understanding recent tendencies in the discipline of urban design in terms of the social construction of a "program of action" (Latour, 1992) at the heart of the professional practices relevant to the built environment.
\end{abstract}

\section{Keywords}

design-oriented research; urban commons; public space; social capital

\section{Issue}

This article is part of the issue "Public Space in the New Urban Agenda: Research into Implementation", edited by Michael W. Mehaffy (KTH Royal Institute of Technology, Sweden), Tigran Haas (KTH Royal Institute of Technology, Sweden), and Peter Elmlund (Axel and Margaret Ax:son Johnson Foundation, Sweden).

(C) 2019 by the author; licensee Cogitatio (Lisbon, Portugal). This article is licensed under a Creative Commons Attribution 4.0 International License (CC BY).

\section{Introduction}

Over the last 30 years, the idea of public space has occupied a central place in both the critical theory and everyday practice of urbanism. This has become even more evident with the release of The New Urban Agenda by the United Nations, emphasizing the importance of public space and "cities for all" as a core component of a project of sustainable development (United Nations, 2016). The apparent erosion of public space by privatization and securitization has been regarded as symptomatic of issues related to economic inequality, racial and ethnic exclusion and environmental injustice. The repair and revitalization of public space has at the same time come to appear as a critical site where those issues are manifested in behavior and experience, and where there are oppor- tunities for significant intervention. The revitalization of public space has become a central piece in efforts to create cities that are safe and supportive of the kind of social cohesion necessary to sustain an inclusive, just and resilient society.

For those with a professional interest in the design and planning of cities, growing interest in public space is an opportunity to bring renewed relevance to their expertise. Over the last half of the 20th century, planners and policy makers have struggled with social problems such as concentrations of poverty, neighborhood decline, disinvestment and gentrification. Where economic justice might be considered "above the pay grade" of the ordinary professional planner, the project of creating safe, comfortable and inclusive public spaces encompasses achievable goals with at least a rhetorical connec- 
tion to broader social issues. In public space, complex social issues of power and inequality can be engaged indirectly and in safely delimited ways, comfortably subsumed in the immediate practical problems of design and management.

There are two contradictory reasons for the growing attention to public space, however. The first is its relationship to the idea of placemaking as an approach to attracting both investment and population to the urban environment. At the same time, the re-making of places sits problematically at the intersection of issues of power, economic inequality, environmental justice and the "right to the city". As cities have confronted the consequences of stark economic inequality, ethnic diversity and unevenly distributed environmental risks, traditional public space has been steadily eroded by privatization and securitization. The reason seems clear: the physical and the social qualities of the city have been undermined by urban decay, disinvestment and problems that go with deepening inequality. In public space, the poor and the powerless become visible, and their mere presence comes to be seen as a problem. The practice of placemaking occupies a political space where the police powers of the state are both activated and called into question.

We have a hopeful perspective that regards the repair of urban public space as a key to repairing the material and social environment of the city. And a critical perspective that highlights the way the repairs themselves become part of the problem, manifesting the essentially contested nature of urban public space and ultimately the dominance of powerful interests in a remaking of the city that systematically serves some and excludes others. Both perspectives share the idea that the quality and character of public space is essential to the quality and vitality of urban public life.

On both sides, the discussion of public space has often relied on unexamined normative assumptions and anecdotal accounts, rather than systematic consideration of available empirical research. This is understandable, given the gaps in the literature. Activists and professionals have an expressed interest in evidence-based approaches to transforming places, but the empirical focus in this work is necessarily narrow and often relies on borrowed and underdeveloped theoretical ideas. The academic literature that does take on the broader issues tends to be relatively disconnected from practice, both because its specialized focus means that it doesn't take up questions relevant to practitioners and because it may call the relevant practices into question in a manner that practitioners find unhelpful.

While planners and activists alike have focused on the implications of Jane Jacobs' insightful observations, there has been less attention to Jacobs' argument that American cities have suffered from a fundamental limitation in the way planners have understood "the kind of problem a city is" (Jacobs, 1961, p. 428). Ironically, Jacobs' advocacy of the city as a complex and emergent phenomenon that can't be reduced to invariant rela- tionships between variables has inspired reform in planning that draws on many of her insights but has largely missed the point of her critique of the reductive tendencies in the supporting research. Limitations in thinking about public space have resulted from a combination of liberal preconceptions and methodological assumptions derived from regarding public space as what Jacobs called "disorganized complexity" (Jacobs, 1961, p. 430).

The purpose here is to suggest a framework for connecting the design-oriented research on accommodating and encouraging social interaction with investigation of broader questions regarding civic engagement, social justice and democratic governance. There are a number of questions underlying this effort: how can we simultaneously attend to the social processes at stake in urban places, the spatial ordering of urban form and the construction of the forms of agency that enable us to make better places on purpose? How can public space be connected more systematically to theories of democratic governance? Complete answers to such questions extend well beyond the scope of this article. An immediate concern is a narrower question of connecting academic research to practice: How can current sociological perspectives contribute to understanding the potential contribution of placemaking and public space to creating more resilient, equitable, and ecologically responsible cities?

This framework involves three theoretical moves that are not usually connected: (1) understanding the sociological implications of public space as an urban commons, (2) connecting the making of public space to research on social capital and collective efficacy, and (3) understanding recent tendencies in the discipline of urban design in terms of the social construction of a "program of action" (Latour, 1992) at the heart of the professional practices relevant to the built environment. Key contradictions in the literature on public space can be sorted out by bringing the discipline-based formation of agency into focus. For whom, by whom and according to what practical logic do we make places in the contemporary urban landscape?

The concept of an urban commons is not a new idea, but it is generally used somewhat superficially, as if it were a simple matter of shared access to space or resources. From a sociological perspective, the idea of a commons emphasizes a public realm that entails a normative order and a relational web that is both spatial and social. The concept of social capital can help to clarify the social processes that constitute a commons in this sense, connecting at the same time to contemporary empirical work regarding the foundations of effective democratic governance (Putnam, 2000). Less directly, social capital can also be connected to the visual and spatial order of the built environment (Sampson, 2013). Finally, the concept of a 'program of action' is a way to bring into analytical focus the implications of situating professional practice at the intersection between built form and social processes. As an illustration of this point, close analysis of 
the example of the New Urbanist movement highlights possibilities and critical challenges associated with restructuring professional practice around urbanism as a normative project. ${ }^{1}$

A neo-liberal logic has been built into much of the conventional thinking about public space, and it is important to note at the outset that a professional reform movement is severely limited in its ability to transcend a logic that has been deeply institutionalized in its field of operations. This neo-liberal logic is implied by the underlying conception of public space, as well as in the preference for private sector and market-oriented solutions, a preference that is structurally defined and ideologically reinforced in the contemporary political economy of place. In order to transcend the limits of this logic, a sociology of public space can move beyond regarding it as a site for social interaction to exploring the active making of places itself as political practice and as potentially a critical component of contemporary "civic innovation" (Sirianni \& Friedland, 2001). Focus on a civic ideal has been reflected in academic work on social capital, following Putnam (2000); implied in the reform of planning practice under the banner of the New Urbanism in the US (Brain, 2008); and called out explicitly in funding initiatives from the non-profit sector (see, for example, the Center for Active Design, 2018). By re-thinking public space as a form of civic practice that has material and spatial dimensions, it is possible open new avenues for research that offer theoretical and practical leverage on problems related not only to the design and management of public space, but to challenges we face in democratic governance of cities.

\section{Public Space as a Research Problem}

Michael Sorkin introduces a volume on the erosion of public space with this claim: "The familiar spaces of traditional cities, the streets and squares, courtyards and parks, are our great scenes of the civic, visible and accessible, our binding agents" (Sorkin, 1992, p. xv). Such claims are often the justification but not the focus of research on public space. The most well-known research on public space falls along a line that runs from Jane Jacobs' anecdotes to William Whyte's methodical observation of "the social life of small urban spaces" (Whyte, 1980). Throughout the literature, the concept of public space contains a useful but problematic ambiguity, as discussions slip from physical space to interactional space, and from an image of public sociability as characterized by Jacobs and others to an image of the idea of the "public realm" as a distinct field of social action (Arendt, 1958; Weintraub, 1995). These conceptions cut across political perspectives on the "grand dichotomy" of public and private, from the liberal/economistic distinction between the state and civil society to the "re- publican virtue" tradition that regards the public realm in terms of "political community and citizenship, analytically distinct from both the market and the administrative state" (Weintraub \& Kumar, 1997, p. 7). This last move-from public space to the public realm-reflects the ways in which ideas about public space contain both deeply rooted liberal conceptions, and a critical impulse toward transcending that impulse.

Much of the design-oriented research follows Whyte's lead, engaging in behavioral observation, interviews, surveys and other tools to capture an empirical representation of "user" experience and behavioral outcomes. Gehl and his colleagues, for example, have pioneered careful observation of qualities of public space associated with accommodating activities that people find necessary, those that might be "optional", and those that are "social", and to be distinguished from the more utilitarian activities (Gehl, 2011, pp 11-12). This kind of research finds its most prominent academic home in environmental psychology, its unit of analysis typically the behavior of individuals in a social setting defined only as interaction with others. Although a broader significance suggested by theoretical discussions from Arendt (1958) to Sennett's "fall of public man" (Sennett, 1974) is often assumed, the dominant line of research effectively avoids confronting underlying political questions regarding the connections between "public space", "public life" and the public realm.

In contrast with the design-oriented literature, critical writing on public space is focused on its characteristics as essentially contested terrain, as both the site and sometimes the focus of conflicts rooted in structures of power and economic inequality, as a space of displacement and spatial exclusion in which underlying social contradictions are revealed and confronted. Such critical perspectives have benefitted from ethnographic approaches that enable rich and detailed exploration of the historical context and the complex layers of meaning at stake in the way such conflicts are played out in urban settings (Low, 2000). Where the tendencies toward securitization and privatization suggest the possible "end of public space", struggles over the "right to the city" point to its on-going importance (Kohn, 2016; Mitchell, 2003). A discourse of rights, however, can easily fail to escape from the core political dilemmas of liberalism - it is ultimately merely the other side of the logic that produces the problems it intends to solve.

Clearly the critical literature on public space tells a somewhat different story from the hopeful threads that run from Jacobs to Gehl, much less the activist organizations such as the Project for Public Space. The designoriented literature reduces public space to a problem of shaping the behavior of individuals-encouraging social interaction by maintaining a safe, comfortable and lively setting that draws individuals and encourages them to

\footnotetext{
${ }^{1}$ This article is part of the issue "Public Space in the New Urban Agenda: Research into Implementation", edited by Michael W. Mehaffy (KTH Royal Institute of Technology, Sweden), Tigran Haas (KTH Royal Institute of Technology, Sweden), and Peter Elmlund (Axel and Margaret Ax:son Johnson Foundation, Sweden).
} 
linger. In pursuit of empirically defensible and eminently practical lessons, this literature aspires to identify discrete patterns of cause and effect, of intervention and outcome. On the other hand, the critical literature tends to defend the idea of public space by focusing on structural conditions and conflicts that interfere with its presumed normative functions, and on the erosion of those normative functions as a manifestation of the broader issues of structural power. The form and character of the space are only contingently relevant, with primary concern given to the underlying structures that determine the dynamics of group conflict.

\section{From Public Space to the Urban Commons}

The gaps and contradictions in the research literature leave us between the horns of a practical dilemma. The positive revitalization of public space, intended to enhance urban livability, is associated with gentrification, displacement and exclusion. Where public space is defined in terms of access and visibility, the problem of free and open access becomes a problem of social control. If public space is defined in terms of open access, its safety and comfort often come to depend on restricting who uses the space and for what purpose. These contradictions are at the heart of common conceptions of public space.

Securitization and privatization are regarded as eroding public space, and yet these two tendencies are precisely the logical solutions to the problem of public space when conceived as a problem of uses and rights in a free society characterized by cultural and class diversity. Although neo-liberal urban reforms are often cited as the culprit in the erosion of public space, they are logically implied by a conception of public space as an open-access resource. As a domain of 'users' to be accommodated, public space is reduced to a collection of individual rights to be asserted and defended without addressing underlying political questions regarding the social and institutional conditions under which rights are negotiated and recognized. Contemporary responses to the perceived problems of public space follow a logical trajectory with roots that go back to Bentham's panopticon-the dark side of the progressive impulse at the heart of classical liberalism (Bentham, 1988; Foucault, 1995). In the face of conflicts around the limits of legitimate police power, cities resort to environmental manipulations intended to discourage undesirable uses and people by increasing surveillance and installing hostile accommodations (e.g., uncomfortable benches to discourage loitering, random sprinklers to discourage sleeping in the grass). When policing and environmental design both prove insufficient to achieve the desired outcomes, privatization is the obvious strategy for expanding the range of legitimate authority to control and exclude.

The classical liberal conception of the public realm is reflected in the idea of the "tragedy of the commons" (Hardin, 1968). Hardin argued that there is an in- escapable problem implied in any situation where there is open access to a resource held in common ownership. Given a world of actors oriented to optimizing their self-interest, the individual benefits of over-exploiting a common resource under the condition of open access outweighs the individual's share of the common cost of harm to that resource. Hence the tragedy: the inevitable destruction of the commons (defined here as common resources not encumbered by private interests) when we assume a condition of individual freedom. When the problem is formulated in this way, there are only two logical solutions: either strong regulation to protect the shared resource, or privatization in such a way that those who reap the benefits also bear the burden of the costs, and thus have an incentive to invest in protection, conservation and/or replacement of those resources.

There are two issues with this framing of the problem of public space. First, what Hardin describes is not a problem of the 'commons', but a problem of openaccess resources. Even so, there are a variety of institutional responses to the management of "common pool resources" that go beyond the stark choice offered by Hardin (Ostrom, 1990). Secondly, although there are some aspects of public space that might be treated as a problem of open access, the essential quality of public space is not in fact defined by common pool resources. Key qualities of public space have to do with the emergent qualities constituted by the cooperative nature of co-presence and shared use.

A key part of the enjoyment, usefulness and meaning of public space is the way it embodies a normative order (Lofland, 1998). Those aspects of public space that are a manifestation of the public realm in the broader sense are not a common pool of resources that can be depleted but a domain of action the value of which is embodied in the norms, patterns of action and shared expectations sustained through shared use. To the extent that use undermines rather than sustaining the conditions necessary for such sharing, public space might be reduced to the problem framed by Hardin's tragedy of the commons. To the extent, however, that public space constitutes a public realm, questions of rights and usage, surveillance and social control, and power and domination are subsumed within a broader fabric of social relations in political society.

Newman's (2015) ethnographic study of popular mobilization around the Jardins d'Éole in Paris offers concrete examples of the way a fabric of social relations can be manifested in public space, in the context of a diverse society. A project to transform a former industrial site into an environmental park became the focus of neighborhood activism during its planning, the site of collective action when completed, and a spatial manifestation of a popular politics that Newman describes as "part of a broader reimagining of what nature, the city, its citizens, and political contestation mean at a fundamental level" (Newman, 2015, p. xv). Mobilization of a marginalized population of West African and Maghrebi 
immigrants took the form of "manif-festives" (Newman, 2015, p. 48), events that combined political expression with carnivalesque celebration. Newman argues that this transformative collective action connected global environmental concerns with local issues of health, safety, and housing. In this way, activists created "a strengthened political consciousness of the 'neighborhood' as a force in favor of democracy" (Newman, 2015, p. 61), and went beyond addressing injustices "to forge a 'civic ecology'" (Newman, 2015, p. 36). In the context of the political culture of French republicanism, with its tendency to regard multiculturalism as social fragmentation and ghettoization, a spatially constructed neighborhood identity became a legitimate way to assert collective claims on behalf of "les gens du quartier" (Newman, 2015, p. 46).

Where it is common for urban redevelopment schemes to entail "displacement and exclusion", Newman sees a different outcome in this mobilization. The interchange between the top-down interests of the French state in transforming a contaminated industrial site into a showcase of French commitment to environmental issues, and the local struggles of an immigrant community in a marginalized neighborhood, produced a "radically vibrant urbanism" (Newman, 2015, p. 198). It is "vibrant" not because of a neutral sociability, but because of the web of engagement that emerged out of conflicts and the creative engagement of the inhabitants. The concept of a civic ecology, then, refers to the way spatial constructions allow for productive expressions of both identity and difference.

Newman suggests replacing the typical concept of "public space" with the concept of an "urban commons". His usage goes beyond the superficial idea of the commons as a space of open access, emphasizing that its character and consequences are the result of a complex process of social and political mediation (Newman, 2015, p. 198). Where the vitality of public space is typically understood in terms of peaceful and orderly social interactions, Newman characterizes the urban commons as a "convergence between conflicting interests, projects, and mediations that can even by marked by acrimony as the boundaries between public/private are blurred" (Newman, 2015, p. 199). More precisely the boundaries between public and private, between particularism and civic or national identity, are negotiated as a practical matter. This "radically vibrant urbanism" is actually the on-going project of social and political order, acted out and mediated in constructions of space and place, through an engagement with the built environment.

\section{Public Space as Civic Ecology}

The sociological literature offers theoretical as well as empirical support for the idea of a civic ecology, identifying social processes that operate in and through spatial practices and the representational qualities inscribed in built form. This support is not always obvious, however. Within the discipline of sociology, one tends to find research in public space rather than research on public space as a distinct socio-spatial phenomenon. Rejection of the functionalism of the Chicago School urban sociologists of the first half of the 20th century has left sociologists suspicious of any suggestion of a functional or deterministic relationship between spatial ecology and social order. The resulting gap in the discipline's attention has only gradually been rectified by the return to interest in the social production of space and place (Gieryn, 2000). In addition to the avoidance of ecological perspectives, Lofland (1998) observes that sociologists have been slow to accept:

The idea that the public realm could be the setting for genuine interaction, the idea that individuals who have no personal relationship with one anotherwho are strangers to one another-the idea that such persons could, in any sociologically meaningful sense, interact. (Lofland, 1998, p. 26)

There are prominent exceptions, of course, in work exploring the orderly processes of interaction in public (Duneier, 1999; Goffman, 1963). Lofland draws a key insight from this line of inquiry: that human activity in the public realm depends on shared norms and expectations, on patterns of action that are sometimes implicitly rather than explicitly cooperative, and that it is comprised of regular forms of interaction that are not simply an impoverished version of what happens in more intimate personal relationships. The public realm is constituted by normatively constructed interactions that sustain a pattern of social relations of a qualitatively distinct type. As a distinctive "social territory", the public realm is a "relational web" that involves persons and places (Lofland, 1998, p. 51).

If the public realm is understood as a relational web that includes relations between people, relations between people and places, and relations between people mediated by place, it is possible to draw a significant theoretical connection to the concept of social capital. This concept has a long history in the social sciences but has been popularized by Putnam (2000) and others who have developed empirical measures and correlated its presence to positive outcomes ranging from civic engagement to reduced crime and even improvements in physical health. What is often lost in the popularization of the concept, however, is that social capital is an attribute of social life embodied not simply in the transactions between individuals but in the emergent properties of a web of associations that constrain and enable those transactions.

In some of the work on social capital, it is defined in terms of the characteristics of social networks that enhance the rational individual's capacity to act (Coleman, 1988). Lin offers a vivid definition of social capital as resources embedded in a network: "your friend's bicycle" (Lin, 2001, p. 56). At the other end of the theoretical spectrum, Bourdieu emphasized the extent to which so- 
cial capital, as any form of capital, has value precisely because it is not evenly distributed (Bourdieu, 1986). For Bourdieu, the importance of social, cultural and educational capital is their role in the reproduction of class differences, in a way that is missed by the methodological individualism often associated with network theory. Where social capital has been regarded as a feature of social networks, or when it becomes a structural variable accounting for individual health or status attainment, the tendency has been to lose sight of a key point in Putnam's work: that empirical measures of social capital are measures of the community's associational cohesion related to the collective capacity for self-governance (Putnam, 1993).

Sampson (2013, p. 38) notes the tendency for social capital to be conceived narrowly as "embodied in the social ties among persons". In this regard, he suggests, social capital theory doesn't move far from the older "social disorganization" theories in explaining such things as crime and neighborhood disorder. Sampson finds, however, that the density of ties doesn't necessarily correlate with lower crime rates or other indications of social disorder. For this reason, he introduces a theory of "collective efficacy", focusing not on the presence of ties but on measures of social cohesion and shared expectations for social control (Sampson, 2013, pp. 151-152). Collective efficacy "elevates an active view of social life that goes beyond the accumulation of stocks of personal resources, such as those found in local ties or civic memberships" (Sampson, 2013, p. 153). According to this theory, "repeated interactions, observations of interactions, and an awareness of potential interactions that could be invoked all establish shared norms (a sense of 'we') beyond the strong ties among friends and kin" (Sampson, 2013, p. 153).

Sampson and Raudenbush (1999) argue that the causal process underlying a variety of correlations, including those that have supported the so-called "broken windows" theory (correlating visual and social disorder), is precisely a process by which associational life becomes a thing sui generis, with emergent properties. Sampson's conception of social capital manifested as collective efficacy refers to a quality of associational life that transcends the specific associations and is linked to place, in three ways: first, it is an empirically observable characteristic of neighborhoods and not necessarily correlated with social characteristics of residents as individuals. This argument is reinforced by evidence regarding the effects of "ecological networks", social connections that are mediated by connections to place (Browning, Calder, Soller, \& Jackson, 2017). Second, it correlates with persistent rates of civic engagement events in a neighborhood (e.g., rates of significant civic memberships are correlated with rates of civic engagement a decade later), as part of a network of neighborhoods (Sampson, 2013, pp. 238-239). Finally, it is linked to the perceptions of visual order in a neighborhood. In this context, the visual order (or disorder) of the neighborhood is an objectified form of collec- tive efficacy, the way we recognize and confirm our perception of the underlying social order (both within and between neighborhoods).

On the basis of systematic observation of neighborhoods, Sampson found that it is the perception of visual disorder and not the systematically observed frequency of the signs of disorder that correlate most closely with such things as crime, suggesting that both crime and visual disorder are related to collective efficacy as a dimension of the spatial logic of neighborhoods. Others have explored the importance of place-based visual cues in the construction of urban social order (Suttles, 1972). In his critique of modern cities, Sennett (1991) describes visual and spatial perceptions of order and disorder in the city as the "conscience of the eye", a more or less developed (or impoverished) capacity for visual and practical engagement with a normative order. In his evocative account, a personal stroll through New York neighborhoods becomes an exemplary engagement with collective life.

Accounts of urban settings from Jacobs to Sennett emphasize the complexity of the social patterns that comprise urban places, noting the way urban places accommodate an array of interactions from "durable engagements" to "fluid encounters" (Blokland, 2017) and that may be characterized by a mix of concerns that range from instrumental interests to sociability, in settings that range in character from private and parochial to public. Blokland describes community as consisting of "practices in which we convey a shared positioning, develop shared experiences, or construct a shared narrative of belonging" (Blokland, 2017, p. 88). We often focus on the ways that narratives of belonging are constructed as narratives of exclusion, but narratives of social distinction can also be simultaneously narratives of belonging. The concept of the "civic" is precisely a narrative of belonging that reflects sharing a commitment to place across the boundaries of differentiated groups.

To the extent that discussions of public space get caught up in the logic of the "tragedy of commons", they are caught within the dilemma associated with the paradoxical "logic of collection action" (Olson, 1971), and stuck therefore with a limited definition of the problem and an even more limited range of solutions. Escape from this dilemma requires introduction of a theory of institutions and organizations, not just individual interests and transactions. This is precisely the point where Putnam introduced the concept of social capital in his account of the foundations of a civic tradition (Putnam, 1993). Putnam quotes Geertz's observation that "cooperation is founded on a very lively sense of the mutual value to the participants of such cooperation, not on a general ethic of the unity of all men or an organic view of society" (Putnam, 1993, p. 168). According to Putnam: "most forms of social capital, such as trust, are what Albert Hirschman has called 'moral resources' - that is resources whose supply increases rather than decreases through use and which become depleted if not used" 
(Putnam, 1993, p. 169). The sociological importance of public space, one might conclude, lies in its character as an urban commons where the most essential shared resources might be "moral resources" that reside in built form, in place itself as a form of social capital, and as a medium for social processes of conflict and mediation.

Social capital, then, is an aspect of the urban commons as a relational web, dependent not just on close interpersonal ties but on the ways in which people are embedded in a relations that span social distance from the most personal to the most impersonal relations. It is a quality of public life that is experienced in concrete associational contexts, manifested as norms of trust and reciprocity that carry over to others with whom one is not directly connected, and infused in the common world of strangers encountered in public space. With this in mind, we can see that the project of what has come to be called 'placemaking' in the professional jargon can be understood as a process of negotiating the inscription of narratives of belonging in spatial form and practices. Although this is often a contested process, Newman's analysis points to the ways that the processes of contestation, manifested in engagement with space and urban form, can produce an overarching relational order.

\section{The Project of Urbanism as a Program of Action}

One of the characteristics of any professional discipline is that the practitioner is trained to deliver certain kinds of solutions to certain kinds of problems. This implies a practice of defining problems in terms of the kinds of solutions the practitioner is prepared to offer. Such a practice depends on a disciplinary formation embedded in the matrix of institutions that define and sustain the professionals' field of operations and authority. In this setting, practitioners elaborate a "program of action" (Brain, 1993; Latour, 1992) that defines the site, those aspects of the site that are potentially in play, the practices of producing authoritative definitions of the problem, and the rhetoric of justification that ultimately authorizes a professional discipline.

For example, we can trace the outlines of the program of action that shaped professional engagement with the processes of urban development in the early 20th century. At the turn of the century in the US, as part of the effort to make sense of changes associated with urbanization, industrialization and immigration, the Chicago School sociologists defined urbanism as a distinctive object for sociological investigation. Starting with empirical exploration of social problems like the concentrations of crime, poverty, alcoholism, and juvenile delinquency, they built a theoretical conception of urbanism as a human ecology (Park, Burgess, \& McKenzie, 1925). It was not accidental that Chicago School sociology developed concurrently with the broad pattern of urban reform associated with the Progressive Era and the early formation of an administrative state with tendrils of power reaching deep into social life.
As social scientists sought to define the city as an object of knowledge, this project was part of a general turn to technical expertise and professional authority in addressing social problems. Professional city managers were to displace machine politics from the business of civic administration. Professionalized social workers replaced the explicit class dynamics of the "charitable visitor" with an authority that was part of the incorporation of social welfare functions into the operations of state power, linking social science to social service (Lubove, 1965). In the first decades of the 20th century, we see the shift from the "city beautiful" to the "city functional", from a focus on visual and symbolic order to a focus on the city as a functional system and planning as the rational administration of that system. In this historical context, urbanism was defined a field of operations for technical rationality, to be informed by scientific knowledge and wielded by professionals whose discipline could impose an objective and practical order to the problems of managing growth and change in the city (Boyer, 1990).

By the late 20th century, professions involved in the planning and design of the built environment had become part of a division of labor deeply embedded in a development regime comprised by the organization of financial capital, the business models and routines of the development industry, a regulatory apparatus that reflected 50 years of bureaucratic accretion and political compromise, and a set of political expectations associated with the liberal "procedural republic" (Sandel, 1996). The program of action associated with professional planning was formed within an institutional matrix that defined the jurisdiction of public-sector planners, shaped business models related to a market for the professional consulting services, and set conditions for the professional division of labor as well as the technical languages and boundary objects that enabled cross-disciplinary communication. Clear examples of the embedded program of action are recognizable in the practices of Euclidean zoning, at the intersection of the police powers of the state and the dynamics of a market for land (Levine, 2006).

Within this institutional matrix, the division of professional labor associated with the production of the built environment both distributes agency and obscures structures of power. It also disconnects professional authority and practice from the experiential and social interactional dimensions of the construction of place, as each practitioner focuses on discrete and specialized problems within the division of labor rather than on an integrated process that engages places as concrete networks of people and things. Compare a traditional public space produced as the direct expression of power with the modern suburban landscape in the US. A public space that is designed in service to institutionalized power is a stage on which social life is played out but also an expression of a relationship of power, in symbolic form but also in the making of the place. Berezin (1997), for example, has explored the dramatizing of urban spaces by the Italian Fascists as part of the construction of their 
power. Mukerji (1997) explores the ways the power of the French monarchy was not only represented but constituted in the form of the gardens at Versailles. In a different but parallel fashion, a four-lane arterial roadway lined with big-box retail set back behind large fields of parking and fast food restaurants on out-parcels manifests other forms of authoritative action and reproduces networks of power. Such spaces are an alienated and obscured but effective manifestation of power in which its workings disappear in a web of distributed authority and instrumental rationality. Furthermore, a neo-liberal logic is built into this institutional matrix, in so far as the division of labor involves routinized collaborations between technical experts and bureaucratic officials, in a context defined by the foundational conditions of the liberal state and markets for land, labor and capital. ${ }^{2}$

Both popular and professional responses to the decay of American cities and the failures of urban renewal programs of the early 1960s indicate the beginning of significant shifts in urbanism as a practice over the course of the following decades. Reception of Gehl's earliest work on public space (1966-1971) points to a turn to the idea of "place" out of a dissatisfaction with the abstract formalism dominating modern architecture. The emergence of "advocacy planning" in the US points to doubts and pressures underlying efforts to reconfigure the professional program of action in the 1970s and 1980s.

The formation of the Congress for the New Urbanism in 1992 reflected the coalescence of a number of professional reform tendencies organized around a critique of the dominant patterns of suburban development, a normative understanding of urbanism and a design-centered program of action. Given the multiple institutional layers and interlocking practices of the contemporary development regime, the movement found itself developing modes of practice that moved against the grain of the dominant institutional arrangements at different levels.

Both critics and advocates of the new urbanism often miss the implications of the critique of bureaucratic rationality in modern planning, as well as the implicit social agenda that has been at the core of the movement (Brain, 2005). In addition to identifying the economic, social and environmental consequences of "sprawl", and behind efforts to recover a nostalgic imagery of traditional places, New Urbanists focused on the unintended consequences of a highly rationalized system that combined bureaucratic rigidity with the fragmented perspectives of specialized expertise. A focus on urban design brought new centrality to their professional role, while they mobilized a normative theory of urbanism in the effort to re-orient planning practice to substantive rather than procedural concerns, focusing on human experience, quality of life and an encompassing (if vaguely defined) conception of a sense of community. Peter Katz, the first executive director of the $\mathrm{CNU}$, characterized the new urbanism as an "architecture of community", articulating a design-centered program of action as a re-forming of human settlements around the social character of places (Katz, 1994).

The key point here is the logic of this strategy, not necessarily its substance. If we look beyond the specifics of New Urbanist projects to the underlying conception of the project of 'urbanism', it is apparent that New Urbanist practitioners found themselves pushing against the limits of the conventional development regime while ultimately remaining embedded within the institutional structures that sustain a professional practice in the context of the contemporary political economy of place (Logan \& Molotch, 1987). Four central ideas run through New Urbanist practice, with implications for a program of action: (1) the neighborhood as the crucial unit of analysis and planning practice, (2) the interconnected patterns of urban form at different levels of scale, from the building to the block, block to the neighborhood, neighborhood to city, city to region, (3) the varied articulation of the relationship between public and private as a defining component of place, and (4) the crucial role of shaping transportation and mobility as a shaping of opportunities for social engagement. A universalized conception of the neighborhood was privileged as a humane scale at which to understand the import of space and place to a pattern of human interactions and relationships. The concept of the urban transect framed the importance of the linkages between built form and social life at different levels of scale, in terms of an ecology of places (Duany \& Brain, 2005).

New Urbanist principles give particular attention to the importance of what they refer to as the public realm, understood in terms of the way the articulation of public and private (e.g., in building frontages) defines the character of public space and manifests a practical responsibility of private actors for the shared world of the street. Pedestrian orientation and multimodal mobility reflect the idea of extending the web of human-scaled relationships from face-to-face interactions in public spaces of the street to a broader civic and even regional connectivity. This orientation toward transportation is set in direct opposition to the mid-century modernist notion that part of being modern is to design for functional efficiency, with particular regard to movement. The impact of the emphasis on place and character in transportation planning has been most dramatically evident in the shifting program of action of traffic engineers (Institute of Traffic Engineers, 2010).

In New Urbanist practice, concern for public space is focused on the idea that the private realm should be arranged in a manner that constitutes a common world, with cumulative and mutual benefits. In addition to setting aside land for parks and plazas as well as civic uses, all private interventions are expected to be mindful of their cumulative effect on their shared setting. Hence the quintessential spaces of urbanism, in this perspective, depend on the way buildings define and give dis-

\footnotetext{
2 In this sense, a neo-liberal logic is manifested in the tendency for reformist solutions to accept the conditions of a capitalist market, and generally to look for ways to move toward policies directed at private rather than public action.
} 
tinctive character to the ordinary space of street and sidewalk. ${ }^{3}$ This conception is manifested in New Urbanist form-based codes as a guide to developing neighborhoods and towns (Parolek, Parolek, \& Crawford, 2008). The effect of a form-based code is to establish a range of defined responsibilities to the common world that anyone choosing to build in the community is expected to take on. In other words, form-based codes regulate the private realm in terms of its role in defining public space.

A normative understanding of urbanism is reflected, then, in two components of New Urbanist practice. First, buildings are expected to contribute to the character of a street, to reinforce the structure and identity of a place, and to enact a shared responsibility in sustaining the quality of a built environment. Second, the quality of urbanism depends on a complex orderliness that can emerge from the diverse contributions of many individuals, over time. Just as one of the satisfactions of the social life of public space is the experience of social order in unplanned encounters, in the accomplishment of social order even in the face of the unexpected disruptions, the New Urbanists have sought to cultivate an appreciation of urbanism as a practice of creating and sustaining places over the long term, of managing change and conserving the sense of identity, coherence and continuitythe work, as they say, of many hands, rather than a design to be attributed to a single author or a technical achievement dependent on an overarching authority.

If this logic could be fully translated into a reconfiguration of the relationship of professional discipline to social and political practice, the implications are potentially profound. The focus on design enables gathering up the fragmented domains of expertise relevant to urban development under a guiding vision grounded in a discipline of urban form. From the standpoint of the sociology of the professions, it can be seen as an effort on the part of design-oriented practitioners (originally, those trained as architects) to assert dominance in the division of labor of expertise in planning. For our purposes here, the point is that the capacity of the designer for integrative problem-solving, when reconceived in the context of engagement with the substantive concerns of citizens and stakeholders, is intended to provide the disciplinary basis for intentional achievement of a normative urbanism. This begs a whole series of questions, of course, regarding the nature of that engagement with citizens and stakeholders. ${ }^{4}$ However, it also contains the seed of a substantive politics of placemaking.

New Urbanist practitioners, in the face of political and economic resistance to their goals, found themselves stepping back from conventional reliance on technical authority in order to find external political leverage necessary to carve out a new role. As a result, practitioners sought a different relationship to the clients/users/citizens of the city. Such a concept of urbanism as a particular kind of design problem, requiring substantive exchanges with non-professionals as well as between the practitioners of relevant expertise, suggests a shift in the locus of agency associated with the production of urban space, and looks to ground its practices in the formative aspirations of a community (rather than the technical issues of civic administration). This tendency appears in the New Urbanist re-invention of the tradition of the charrette (originally distinctively associated with architecture) as a collaborative design process that requires engagement in real time with community members, elected and appointed officials, and other experts (Brain, 2008). Although early successes of a charrette-based process quickly gave way to a scaling back and routinization in practice, it nonetheless raises the question of how one might create a space for genuine and inclusive collaboration in the formation of an intentional urbanism. Even the modest successes of the process with respect to building consensus around design solutions suggest the ways that a design vocabulary and approach can become part of the way people think about public space as a manifestation of a civic politics in which the boundaries of private interest and public good can be negotiated as a practical matter.

Ultimately, however, the very success of the New Urbanist movement, and its ability to articulate a rhetoric of justification that has become a kind of orthodoxy in public sector planning in the US, has meant that practitioners have been compelled to craft an accommodation with the dominant institutional and ideological arrangements of American urban development-i.e., the organization of capital in the development industry, the regulatory apparatus associated with the liberal state, and the division of professional labor among experts. Although there are currents of concern for issues of social and environmental justice in New Urbanist discourse, for example, these concerns are blunted and often washed out entirely in settings where the logic of neo-liberal reform holds political and economic sway.

In many respects, the New Urbanist movement has been a beneficiary of the failures associated with the policies of urban renewal of the 1960s. By offering a marketable image of urbanism associated with a variety of social benefits, the movement could provide compelling justification for policies that turned from the much-criticized "top down" responses to urban decline to the strategic enlistment of private capital and market dynamics to spur reinvestment and redevelopment. This aspect of New Urbanist success has been the focus of much of the criticism leveled at New Urbanist projects. Even so, the success of this rhetoric of justification has also depended on its ability to evoke a narrative of urbanism as a collaborative project, in terms that have had the

\footnotetext{
${ }^{3}$ Obviously the New Urbanists cannot claim a monopoly on this idea. The point is that it forms a critical piece of the New Urbanist account of urban placemaking.

4 Even the language here is problematic, of course. Both "citizen" and "stakeholder" have been associated with drawing boundaries of inclusion and exclusion from such processes. Referring to people as "users" has other problems.
} 
capacity to engage and resonate with community members. In the absence of a clear articulation of a civic politics linked to this project of urbanism, however, rejection of top-down policy solutions slips all too comfortably into neo-liberalism.

David Harvey (2000, p. 169) has suggested that the New Urbanism "does battle with conventional wisdoms entrenched in a wide range of institutions (developers, bankers, transport interests, etc.)". He writes: "It attempts intimate and integrated forms of development that by-pass the rather stultifying conception of the horizontally zoned and large-platted city. This liberates an interest in the street and civic architecture as arenas of sociality" (Harvey, 2000, p. 169). At the same time, he observes that New Urbanists have put too much faith in the ideal of community without coming to terms with "the darker side of communitarianism" (Harvey, 2000, p. 170). Harvey also points out that many of the mistaken presumptions of the New Urbanists - the lack of clarity that comes with the conflation of neighborhood and community, the difficulty with resolving problems that occur at different scales, even the difficulty addressing underlying structural challenges-have to do with the fact that "the 'new urbanism' must, if it is to be realized, embed its projects in a restrictive set of social processes" (Harvey, 2000 , p. 173). This constraint, however, is predicated on the extent to which its practices remain embedded in the institutional arrangements that sustain a particular matrix of professional disciplines-both the fee-for-service consultancies and the integration into the administrative state. The analysis here suggests that there might be another way for this to play out. The effort to materialize what Harvey calls a utopian vision-or what we might refer to as an urban ideal-suggests a pragmatic conception of community that can be productively aligned with current sociological thinking regarding social capital.

The tension between this urban ideal and the processes for its realization have manifested as internal contradictions and struggles within the New Urbanist movement, illuminating core contradictions in the embedding of a professional practice of urbanism in a broader development regime. In the last few years, these contradictions have motivated several tendencies that attempt to move beyond the conventional limits of professional planning and urban design. It has been manifested in the emergence of tactical urbanism (Lydon \& Garcia, 2015), and in the initiatives for Lean Urbanism (Dittmar \& Kelbaugh, 2019) and incremental development (Brain, 2019). The contradictions are far from resolved but appear with growing clarity. Lean Urbanism, for example, has not always confronted the implications of what becomes at times a libertarian distrust of the bureaucratic state. With respect to tactical urbanism, its significance has tended to shift as it has moved from the creativity of unsanctioned "guerilla" interventions toward being reduced, in the worst case, to some- what cliched gestures with only superficial connection to bottom-up engagement.

A critical limitation of the New Urbanist movement has been its tendency to oscillate between top-down policy intended to manipulate market outcomes and bottom-up faith in the market itself-essentially, in political terms, the inability to move past the limits of contemporary liberalism. In the US, this tension is reflected in the arguments between the advocates of "Smart Growth" who focus on policies intended to incentivize different development patterns, and the advocates of traditional neighborhood design who focus on designing compact neighborhoods that can offer people that choice. Neither top-down policy nor design-based approaches are able to take up the underlying structural issues that are rooted in the political economy, nor are they able on their own to find a way out of this bottomup/top-down dichotomy. Those who operate in the domain of policy, as well as those who operate in the domain of a market for professional services, are structurally constrained when it comes to confronting the fundamentally political character of the normative urbanism to which they aspire. To a large extent, this can be understood as a problem of agency.

Even with its shortcomings in practice, the normative theory of urbanism at the heart of the New Urbanist movement implies what Sandel (1996) has referred to as a formative vision that points beyond its limits as a professional movement and suggests a connection with efforts to re-create the foundations of democratic political capacity, in and through self-conscious and (one would hope) inclusive practices of placemaking. Such a normative theory of urbanism implies situating a practice of design in explicit relation to the native processes of social connection to place, and to places as a way to sustain social meaning. This is not an easy thing to accomplish, and has generally produced a reductionistic tendency, if for no other reason than the need to shore up a professional role. The New Urbanist movement has highlighted some of the challenges in its efforts to resolve issues that might seem exclusively the specialized domain of urban designers: for example in the effort to come to terms with the idea of tradition, and the difficult relationship between self-conscious formal intentions and vernacular building (Krier, 2009). Even the idea of the new urbanism as 'neotraditional' might be read as an urge to go beyond nostalgic references toward engagement with the social processes of constructing meaning over time. New Urbanist work has brought some of the dilemmas of design to the surface, although it has fallen short of the potential for to play a more profound transformative role. ${ }^{5}$

\section{Conclusion: Urbanism as a Political Project}

At the heart of the New Urbanist project, even where it falls short of its aspirations, one can identify a call to heal

\footnotetext{
${ }^{5}$ The discussion of so-called "everyday urbanism" has also recognized the importance of bottom-up processes of placemaking but tends ultimately to lack the transformative capacity associated with the critical components of any sort of utopian vision (Chase, Crawford, \& Kaliski, 2008).
} 
the disruptions of the urban commons as a spatial realization of social connection and collective intentions, disruptions that have been the result of the way institutionalized patterns of urban development in the 20th century have fragmented the processes of placemaking. Implied in a normative conception of urbanism, New Urbanist or otherwise, there is a recognition that the way we articulate the intersection of public and private space in the city is a consequential enactment of a structure of social relations. It can be structurally and institutionally determined, an artifact of a history that operates over our heads and behind our backs, or it can be more or less the product of intentional and self-conscious action. The theory and research cited above suggest that the way we give form to urban space is not simply a cause of behavior, but itself a form of human action that embodies social relationships. In this respect, design matters because it is itself a form of action involving a process of making significant choices and inscribing intentions in a visual and spatial order. It matters what kind of intentions are presumed to be relevant and possible, as well as for whom and by whom they are to be articulated and implemented.

The idea of placemaking has gained wide currency since Gehl first used a focus on place as a starting point for articulating a practical alternative to the abstraction of modernist architectural practice (Gehl, 2011). As a concept, placemaking is often invoked precisely because it allows for a slide between different dimensions of place without necessarily being compelled to clarify how they are (or are not) related. This also helps to avoid the question of agency in placemaking-who is doing what, for whom?

This conceptual slippage is apparent in a lot of the talk by activist organizations. The Project for Public Spaces describes "placemaking" as "a collaborative process in which people come together to create vital public spaces that bring health, happiness, and social connections to their communities (Project for Public Spaces, 2018, p. 40). When they break down the 11 principles of placemaking, the first principle is "the community is the expert" (Project for Public Spaces, 2018, p. 43). However, this principle simply reflects the circular insight that places that engage people are places that the people occupying them are engaged in making. What is really at stake in the formation of placemaking as a program of action? How is such a practice constructed and situated in the matrix of institutions on which it inevitably depends? There are, as we can see, many ways in which it can go astray from the ostensible goal of inclusivity, equity and empowerment.

Arefi (2016) has sorted placemaking into a three-part typology of needs, opportunities and asset-based approaches. Placemaking can be a response to local needs, as when a government chooses to build a settlement to accommodate rural-to-urban migration, or it can be a response to an opportunity, as when squatter settlements form as a direct response to the same needs (Arefi, 2016, p. 6). The asset-based approach has grown out of the work of community organizers who have recognized that community resilience and prosperity are best served by cultivating social, economic and political capacity from within a community, rather than relying on either experts or outside institutions to address needs (Kretzmann \& McKnight, 1993; McKnight, 1996; McKnight \& Block, 2010). This approach has been articulated in direct opposition to the needs-based approach to social problems by conventional social service agencies and the liberal state.

Arefi's typology identifies different modes of agency associated with each type of placemaking. The first distinction is between the top-down agency of governments or other organized entities, typically relying on technical experts, and agency mobilized from the bottom up, relying on local knowledge. The asset-based approach reflects a third way, in which agency is constituted by social connection that activates assets already present in the community in ways previously unrecognized, underutilized or simply not accessible in a manner relevant to the community's needs and aspirations (i.e., the skills and knowledge of individuals, the resources of organizations and associations from businesses and churches to civic associations, and the assets available through public and private institutions). An important aspect of this approach is that it avoids a misleading dichotomy of top-down and bottom-up resources, allowing for communities to use the power of association to mobilize assets in a manner that also optimizes their capacity to take advantage of external connections and partnerships with institutional actors who bring resources, broader connections and access to expert knowledge (i.e., connections that Putnam refers to as "bridging" social capital).

From the sociological perspective presented here, the urban public realm is a relational web of people and places, and a moral resource of civic life sustained by the formation of social capital and sustaining the foundations for collective efficacy as well as relational narratives of belonging. It is constituted by the ability to give objective form to the quality and character of collective life across the range of social encounters from private to public, with all their conflicts, ambiguities and complexities. This sociological conception parallels the idea of a civic ecology that is realized in relations and interactions mediated by their inscription in built form, and potentially activated by engagement in the processes of giving intentional form to places. It is more than a domain in which individual action is aggregated, more than just a space of pedestrian traffic and sociability. It is a normative universe that is sustained by the action within it. If public space is reimagined as an urban commons understood in terms of the social structures and processes that shape and sustain it, we need to re-think what we imagine ourselves to be doing when we seek purposefully to create, improve or revive urban public space.

In the research on public space that focuses on the relationship between design and behavior, the agency and 
the authority of the designer are assumed rather than examined. Critical and ethnographic studies of public space situate the formal intentions of designers and other social actors in the context of structures of power and conflicting interests, in the context of broad cultural patterns, and in relation to historical contingencies. There is a significant gap between research agendas that focus on the social character of place and those that regard place as a material and spatial phenomenon with social and behavioral impact. One way to bridge that gap can be understanding the formation of the socio-technical program of action that enables placemaking to become a self-conscious practice, and that constitutes the discipline and role orientation of the professionals involved.

The practices of design involve a certain set of skills and expertise in a process of articulating self-conscious and purposeful choices in the built environment. Such practices might be integrated more deeply with the practices of asset-based community development, in the context of a theory of public space as civic practice that self-consciously articulates the connection of social relations to place. Toward this end, design-oriented research needs to draw on the insights from research that links the production of visual order/disorder with the formation of social capital and collective efficacy.

Typically, the professional practitioner relies on linking expert action to technical rationality, framed within a discipline that offers a rhetoric of justification for professional solutions (and particularly situated definitions of the problem). A program of action that conceives of urban design in terms of a normative theory of urbanism reinforces its potential as a civic art-not in the older sense of artists acting in service to civic goals, but design as a process that engages the narrative building processes and production of symbolic capital in the urban setting as sites of contestation and mediation in diverse communities. In this way, design practitioners can help to activate a civic sensibility, to motivate and inform civic innovation, in and through the integration of the practical perspective and boundary-crossing resources of the outside expert with local knowledge in a reflexive and critical fashion.

We might ask, then: what kind of design practice would make this self-conscious and purposeful, a formative project that is also inclusive, a city that is both for all and by all? This is perhaps the most significant promise at the heart of the turn to placemaking: the possibility of an intentional urbanism capable of transforming public space into an urban commons. This research needs to bring into focus the active connection between professional discipline, cultural traditions, historical conditions, and the purposeful engagement of citizens. If it is possible to liberate, as Harvey suggests, the physical space of the city as a domain of sociality, what might it take to re-configure planning practice around urbanism as a domain in which design intelligence becomes part of broader processes of civic engagement and political action?

\section{Acknowledgments}

Research on the New Urbanist movement was supported by a fellowship from the National Endowment for the Humanities (Grant number FB-34882-98) and a grant from the Graham Foundation for the Fine Arts (1998).

\section{Conflict of Interests}

The author declares no conflict of interests.

\section{References}

Arefi, M. (2016). Deconstructing placemaking. Needs, opportunities and assets. New York, NY: Routledge.

Arendt, H. (1958). The human condition. Chicago, IL: University of Chicago Press.

Bentham, J. (1988). The principles of morals and legislation. Amherst, NY: Prometheus Books.

Berezin, M. (1997). Making the fascist self. The political culture of interwar Italy. Ithaca, NY: Cornell University Press.

Blokland, T. (2017). Community as practice. Cambridge: Polity Press.

Boyer, C. (1990). Dreaming the rational city: The myth of American city planning. Cambridge, MA: MIT Press.

Bourdieu, P. (1986). Distinction. A social critique of the judgment of taste. New York, NY: Routledge.

Brain, D. (1993). Cultural production as 'society in the making': Architecture as an exemplar of the social construction of cultural artifacts. In D. Crane (Ed.), The sociology of culture. Emerging theoretical perspectives (pp. 191-220). Oxford: Basil Blackwell.

Brain, D. (2005). From good neighborhoods to sustainable cities: Social science and the social agenda of the new urbanism. International Regional Science Review. Special issue edited by Gerrett Knaap and Emily Talen.

Brain, D. (2008). Beyond the neighborhood: New urbanism as civic renewal. In T. Haas (Ed.), New urbanism and beyond. Designing cities for the future (pp. 249-254). New York, NY: Rizzoli.

Brain, D. (2019). The practice of urbanism: Civic engagement and collaboration by design. In C. Kickert \& M. Arefi (Eds.), The Palgrave handbook of bottomup urbanism (pp. 51-66). New York, NY: Palgrave Macmillan.

Browning, C., Calder, C., Soller, B., \& Jackson, A. (2017). Ecological networks and neighborhood social organization. American Journal of Sociology, 122(6).

Center for Active Design. (2018). Assembly. Civic design guidelines. New York, NY: Center for Active Design.

Chase, J., Crawford, M., \& Kaliski, J. (Eds). (2008). Everyday urbanism. New York, NY: The Monacelli Press.

Coleman, J. (1988). Social capital in the creation of human capital. The American Journal of Sociology, 94, 95-120.

Dittmar, H., \& Kelbaugh, D. 2019. "Lean urbanism is 
about making small possible" In C. Kickert \& M. Arefi (Eds.), The Palgrave handbook of bottom-up urbanism (pp. 67-82). New York, NY: Palgrave Macmillan.

Duany, A., \& Brain, D. (2005). Regulating as if humans matter: The transect and post-suburban planning. In E. Ben-Joseph \& T. S. Szold (Eds.), Regulating place: Standards and the shaping of urban America (pp. 293-332). New York, NY: Routledge.

Duneier, M. (1999). Sidewalk. New York, NY: Farrar, Strauss and Giroux.

Foucault, M. (1995). Discipline and punish. New York, NY: Vintage Books.

Gehl, J. (2011). Life between buildings. Using public space. Washington, DC: Island Press.

Gieryn, T. (2000). A space for place in sociology. Annual Review of Sociology, 26, 463-496.

Goffman, E. (1963). Behavior in public places. Notes on the social organization of gatherings. New York, NY: The Free Press.

Hardin, G. (1968). The tragedy of the commons. Science, $162,1243-1248$.

Harvey, D. (2000). Spaces of hope. Berkeley, CA: University of California Press.

Institute of Traffic Engineers. (2010). Designing walkable urban thoroughfares: A context-sensitive approach. Washington, DC: ITE.

Jacobs, J. (1961). The death and life of great American cities. New York, NY: Random House.

Katz, P. (1994). The new urbanism: Toward an architecture of community. New York, NY: McGraw-Hill.

Kohn, M. (2016). The death and life of the urban commonwealth. New York, NY: Oxford University Press.

Kretzmann, J., \& McKnight, J. (1993). Building communities from the inside out: $A$ path toward finding and mobilizing a community's assets. Chicago, IL: AssetBased Community Development Institute.

Krier, L. (2009). The architecture of community. Washington, DC: Island Press.

Latour, B. (1992). Where are the missing masses? The sociology of a few mundane artifacts. In W. Bijker \& J. Law (Ed.), Shaping technology, building society. Studies in sociotechnical change (pp. 225-258). Cambridge, MA: MIT Press.

Levine, J. (2006). Zoned out. Regulation, markets, and choices in transportation and metropolitan land use. New York, NY: Routledge.

Lin, N. (2001). Social capital: Theory and research. Cambridge: Cambridge University Press.

Lofland, L. (1998). The public realm. Exploring the city's quintessential social territory. Hawethorne, NY: Aldine De Gruyter.

Logan, J., \& Molotch, H. (1987). Urban fortunes. The political economy of place. Berkeley, CA: University of California Press.

Low, S. (2000). On the plaza. The politics of public space and culture. Austin, TX: University of Texas Press.

Lubove, R. (1965). The professional altruist: The emergence of social work as a career, 1880-1930. Cam- bridge: Harvard University Press.

Lydon, M., \& Garcia, A. (2015). Tactical urbanism. Shortterm action for long-term change. Washington, DC: Island Press.

McKnight, J. (1996). The careless society: Community and its counterfeits. New York, NY: Basic Books.

McKnight, J., \& Block, P. (2010). The abundant society: Awakening the power of families and neighborhoods. San Francisco, CA: Barrett-Koehler Publishers.

Mitchell, D. (2003). The right to the city. Social justice and the fight for public space. New York, NY: The Guilford Press.

Mukerji, C. (1997). Territorial ambitions and the gardens of Versailles. Cambridge: Cambridge University Press.

Newman, A. (2015). Landscape of discontent: Urban sustainability in immigrant Paris. Minneapolis, MN: University of Minnesota Press.

Olson, M. (1971). The Logic of collective action. Public goods and the theory of groups. Cambridge, MA: Harvard University Press.

Ostrom, E. (1990). Governing the commons: The evolution of institutions for collective action. Cambridge: Cambridge University Press.

Park, R., Burgess, E., \& McKenzie, R. (1925). The city. Chicago, IL: University of Chicago Press.

Parolek, D., Parolek, K., \& Crawford, P. (2008). Formbased codes. A guide for planners, urban designers, Municipalities, and Developers. Hoboken, NJ: John Wiley and Sons.

Project for Public Spaces. (2018). How to turn a place around. New York, NY: PPS.

Putnam, R. D. (1993). Making democracy work. Civic traditions in modern Italy. Princeton, NJ: Princeton University Press.

Putnam, R. D. (2000). Bowling alone. The collapse and revival of American community. New York, NY: Simon and Schuster.

Sampson, R. (2013). The great American city. Chicago and the enduring neighborhood effect. Chicago, IL: University of Chicago Press.

Sampson, R., \& Raudenbush, S. (1999). Systematic social observation of public spaces: A new look at disorder in urban neighborhoods. American Journal of Sociology, 105(3), 603-651.

Sandel, M. (1996). Democracy's discontent. America in search of a public philosophy. Cambridge: Harvard University Press.

Sennett, R. (1974). The fall of public man. New York, NY: Vintage Books.

Sennett, R. (1991). The conscience of the eye. The design and social life of cities. New York, NY: Alfred A. Knopf.

Sirianni, C., \& Friedland, L. (2001). Civic innovation in America. Berkeley, CA: University of California Press.

Sorkin, M. (Ed.). (1992). Variations on a theme park. The new American city and the end of public space. New York, NY: Hill and Wang.

Suttles, G. (1972). The social construction of communities. Chicago, IL: University of Chicago Press. 
United Nations. (2016). The new urban agenda. New York, NY: United Nations-Habitat III.

Weintraub, J., \& Kumar, K. (1997). Public and private in thought and practice: Perspectives on a grand dichotomy. Chicago, IL: University of Chicago Press.

Weintraub, J. (1995). Varieties and vicissitudes of public space. In P. Kasinitz (Ed.), Metropolis. Center and symbol of our times (pp. 280-319). New York, NY: New York University Press.

Whyte, W. (1980). The social life of small urban spaces. New York, NY: PPS.

\section{About the Author}

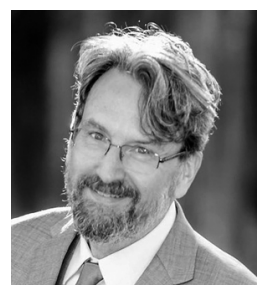

David Brain studied architecture at the University of Cincinnati before an interest in urban issues led him to a PhD in Sociology at Harvard University. His research and publications have focused on architecture, urbanism, and the connections between place-making, community-building, and civic engagement. He is currently a Professor of Sociology and Environmental Studies at the New College of Florida, and a Research Associate with the Center for the Future of Places, KTH, Stockholm. 